\title{
Assessment of water availability vulnerability in the Cerrado
}

\author{
Daniel Althoff ${ }^{1}\left[\right.$ ] Lineu Neiva Rodrigues ${ }^{1,2} \cdot$ Demetrius David da Silva $^{1}$
}

Received: 10 June 2021 / Accepted: 18 October 2021 / Published online: 25 October 2021

(c) The Author(s) 2021

\begin{abstract}
Many basins in the Cerrado biome already face increases in water disputes caused by agricultural expansion without longterm planning and monitoring of natural resources. The amount and timing of water availability are crucial for the socioeconomic development of agricultural activities and climate change resilience enhancement in the Cerrado. This study relied on a dataset developed for the Cerrado to characterize its climate and current water availability status. Different climate indices and hydrological signatures were adopted to describe the energy and water budget, climate seasonality, flow magnitude, flow dynamics, and average duration of low-flow events. Risk analysis was carried out to classify the monthly risk severity and identify periods and regions under a higher pressure regarding water availability in the Cerrado. Overall, the water availability is higher in the western and southern regions and lower in the eastern and northern regions, which experience a transition to a humid and semiarid climate, respectively. The water resources in the Cerrado occur under the highest pressure in September and October. We also identified regions with the potential to increase sustainable water use. These regions exhibit a low ratio between the flow equal to or exceeded $95 \%$ of the time and the mean flow $\left(Q_{95} / Q\right)$, which indicates that sustainable water use may be improved with techniques related to flow regularization and rainwater/runoff harvesting.
\end{abstract}

Keywords Climate indices $\cdot$ Hydrological signatures $\cdot$ Sustainable water use $\cdot$ Water scarcity

\section{Introduction}

The importance of the Cerrado biome (the Brazilian tropical woodland savanna) has been recognized both as a biodiversity hotspot, with the richest flora among all of the savannas worldwide (Lambers et al. 2020), and for its notable presence in the national economy (Lemes et al. 2020). For many years, the Cerrado has remained a focal area for agricultural investment and expansion (Lemes et al. 2020; Spera 2017). In the 1980s, Cerrado agriculture was responsible for the transition of Brazil from a net importer of grain to one of

Daniel Althoff

daniel_althoff@hotmail.com

Lineu Neiva Rodrigues

lineu.rodrigues@embrapa.br

Demetrius David da Silva

demetrius@ufv.br

1 Department of Agricultural Engineering, Federal University of Viçosa (UFV), Av. Peter Henry Rolfs, s.n, Viçosa, MG 36570-900, Brazil

2 Brazilian Agricultural Research Corporation (EMBRAPA) Cerrados, BR-020, Km 18, Planaltina, DF 73310-970, Brazil the major grain producers globally (Hosono et al. 2016). The biome itself is responsible for more than half of the soybean and beef production of Brazil (IBGE 2017; Klink 2014).

Cerrado soils exhibit a good physical structure but are acidic and infertile. The agricultural success of this biome mainly stems from improvements in management practices and high technological and fertilization inputs (Hosono et al. 2016; Lambers et al. 2020). Another key factor responsible for the achieved agricultural success in the Cerrado is its climate. The Cerrado climate is mainly classified as a tropical savanna climate with dry winters (Alvares et al. 2013). This climate is characterized by warm seasons with plentiful rainfall and sunlight to permit abundant plant growth. It is common for regions to benefit from a long wet season and the implementation of double cropping to increase profitability (Spangler et al. 2017).

Despite the Cerrado agricultural success, considered by some as miraculous (Rada 2013), it is also controversial. Agricultural expansion has caused landscape fragmentation, biodiversity loss, soil erosion, and pollution of water resources (Lambers et al. 2020; Lemes et al. 2020; Lima and Persson 2020; Rada 2013; Souza et al. 2020). Moreover, climate change projections have estimated warming 
trends, a decrease in consecutive wet days, an increase in dry season length (Chou et al. 2014; Pires et al. 2016), and a decrease in water availability in river streams (Oliveira et al. 2017). These projections jeopardize the success of agriculture, especially rainfed agriculture. Different studies have indicated that the conservancy of remnants of the Cerrado could be fundamental in climate change mitigation (Costa and Pires 2010; Pires et al. 2016). With the use of a climate model and deforestation scenarios pertaining to the Cerrado, Costa and Pires (2010) showed that rainfall will decrease in most months and that the dry season will become longer. Alternatively, the intensification of agriculture practices in already degraded pastures could be a way to provide economic development while avoiding expansion into natural ecosystems (Spera 2017).

Possible beneficial effects have been reported regarding agricultural intensification in different parts of the world. Although not the objective of agricultural intensification and/or irrigation expansion, Mueller et al. (2016) argued that its side effects include an increase in potential evapotranspiration on hotter days, which contributes to precipitation recycling and a decrease in temperature. Lathuillière et al. (2016) also reported a possible increase in precipitation recycling due to irrigation expansion into already cultivated areas. Kueppers, Snyder, and Sloan (2007) examined irrigation cooling effects on a regional scale in California and suggest that irrigation results in a significant decrease in monthly mean and maximum temperatures during the dry season. Other strategies for agricultural intensification have included rainwater/runoff harvesting, which could increase water availability during drought periods for irrigation purposes (Pinhati et al. 2020; Rodrigues et al. 2012). Fortunately, in the Cerrado, the potential to expand its irrigated areas has been reported, at approximately 26.5 Mha (FEALQ 2014), while the current irrigated area of Brazil remains below 8 Mha.

In Brazil, water resource management and planning have usually developed in regions or hydrographic basins where conflicts have arisen from restrictions related to a low water availability, e.g., the Brazilian semiarid region, or an excess in demand, e.g., large cities (ANA 2014). Managers should be aware, however, that poor water resource management and planning and a lack of proper information in data-scarce regions may cause more harm than good, especially concerning irrigation strategies (He et al. 2017). Thus, improved knowledge on water availability is critical not only to support better public policies (e.g., irrigation, energy production, and water supply) but also to support the formulation of more effective water management tools (e.g., water permits). Despite the considerable water availability in the Cerrado for irrigation expansion purposes (FEALQ 2014), there are regions where expansion has occurred under poor planning and little hydrological information, thereby aggravating water use conflicts (Pousa et al. 2019). Particularly in the Cerrado biome, many basins already face increased disputes over water use because of the accelerated development of agriculture disassociated from long-term planning and monitoring of its natural resource uses (Rodrigues 2018).

The amount and timing of water availability are crucial for the socioeconomic development of agricultural activities in the Cerrado, as well as to increase its resilience to climate change. Furthermore, the dry season and drought periods, along with projections of increased droughts, have constrained the continued development of the Cerrado (Rodrigues et al. 2020). Thus, the objective of this study was to characterize the water availability in the Cerrado in terms of its surface water sources, define those periods with a higher pressure on resources, and identify regions where sustainable water use could be increased through local storage of excess runoff and regularization. This information is important for integrated water resource management improvement and to help identify which regions should be assigned higher priorities or would better benefit from investment allocation by the government.

\section{Material and methods}

This section first presents the study area and the streamflow and meteorological forcings considered in this study. These data are employed to provide context to the water availability status of the Cerrado by deriving various climate indices and hydrological signatures, as described in the following subsections. In this study, the water availability is examined in terms of the water available from surface sources and largely characterized by hydrological signatures related to the flow distribution. The last two subsections describe the risk classification proposed herein and the identification of regions with a potential for sustainable water use improvement.

\section{Study area}

The Cerrado occupies approximately $23 \%$ of the Brazilian territory (Fig. 1a) and yields water for many of the main hydrographic regions of Brazil (Lima 2011). The Cerrado hydrography is shown in Fig. $1 \mathrm{~b}$ at a spatial resolution of 1:250,000 (ANA 2020), showing its river flow distribution to many bordering regions. Its climate is mainly characterized as a tropical savanna climate with dry winters (Alvares et al. 2013), i.e., two well-defined seasons with a mean monthly temperature above $18{ }^{\circ} \mathrm{C}$ in all months, and the precipitation in the driest winter month is below $60 \mathrm{~mm}$. The climate transitions to a hot semiarid climate bordering the Caatinga, a tropical monsoon climate bordering the Amazon and Pantanal, and a temperate climate bordering the Atlantic Forest. These transition areas are important to better understand the 

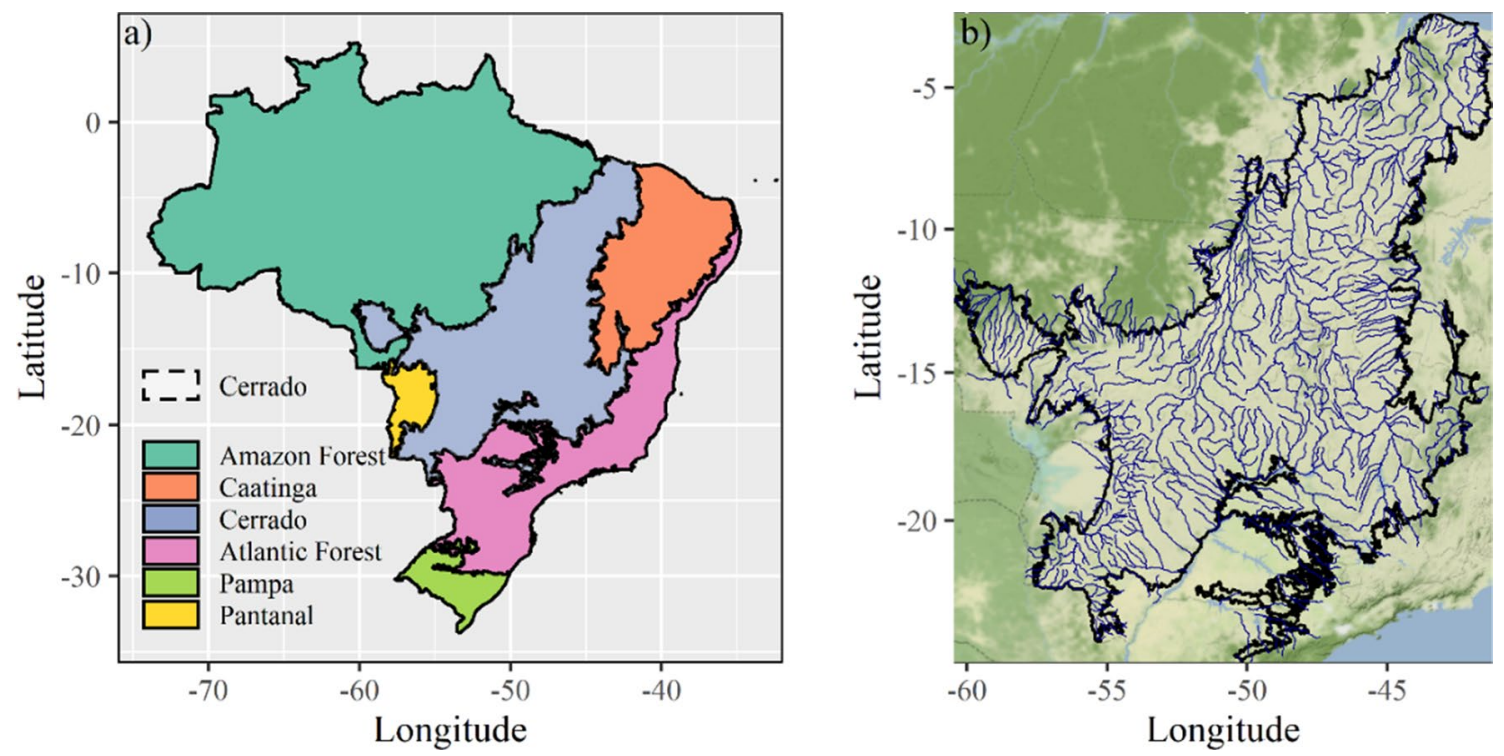

Fig. 1 a Brazilian biomes (data source: IBGE, 2019) and b Cerrado hydrography (data source: ANA, 2020)

climate variation across the Cerrado, especially concerning irrigated agriculture because of the precipitation distribution throughout the year.

\section{Streamflow and meteorological forcings}

HydroCerrado is a dataset describing the catchments in the Cerrado biome (Althoff et al. 2021b). In addition to information compiled for gauged catchments, the HydroCerrado dataset also includes the boundaries (Fig. 2a), meteorological forcings (Fig. 2b), and streamflow series (Fig. 2b) estimated for all (4531) level 5 ottobasins. Ottobasins comprise hydrologic units (basins and interbasins) classified according to the Pfafstetter hierarchical classification (Furnans and Olivera 2001). Ottobasin streamflow series were simulated based on the regionalization of parameters calibrated against the GR5J rainfall-runoff hydrological model (Le Moine 2008; Pushpalatha et al. 2011). Although much uncertainty (a)

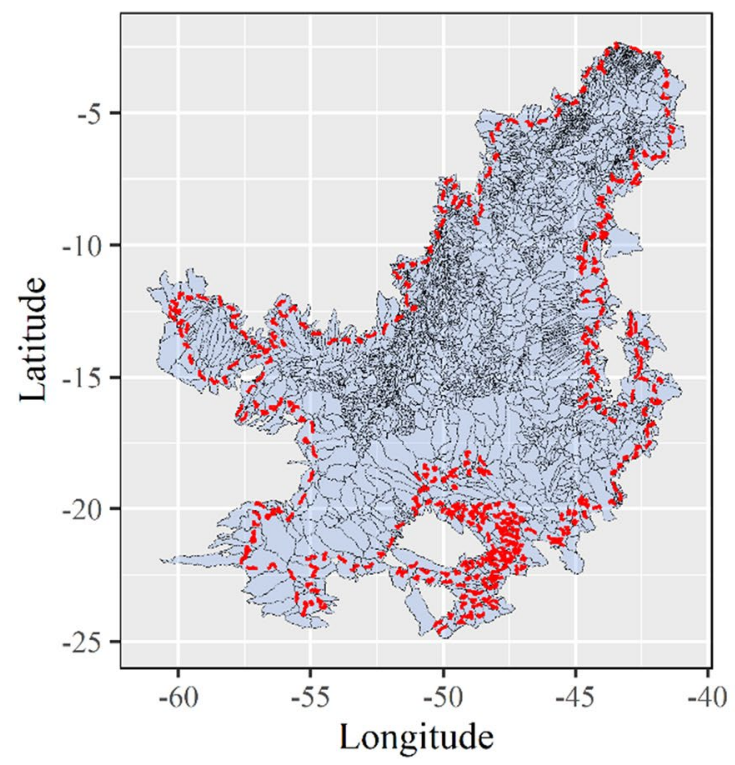

(b) Reference evapotranspiration
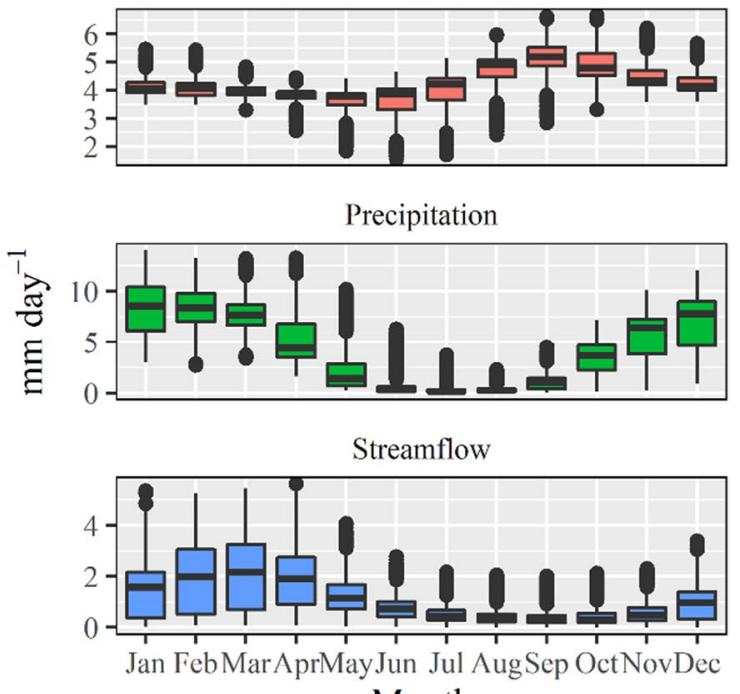

Month

Fig. 2 a Boundaries of all level 5 ottobasins in the Cerrado and $\mathbf{b}$ their respective mean monthly reference evapotranspiration, precipitation, and streamflow 
can occur in streamflow series obtained via regionalization, this is the best dataset available in regard to the hydrologic units at this resolution. Furthermore, Althoff et al. (2021c) reported the Kling-Gupta (Gupta et al. 2009) and the relative Nash-Sutcliffe (Krause et al. 2005; Nash and Sutcliffe 1970) efficiencies to be 0.58 and 0.56 , respectively, for the regionalization technique adopted and that hydrological signatures derived from streamflow series obtained for ottobasins attain a good spatial agreement with those derived from observed streamflow series.

The dataset covers the period from 2003 to 2014. The streamflow series are based on the regionalization of hydrological models and gridded data available from 2000-06-1 to the near present. However, the observed streamflow data used to calibrate the models employed for regionalization only contained a quality check guaranteed by the Brazilian National Water Agency (ANA) until 2014. The period from 2000-06-01 to 2002-12-31 was thus adopted as a warmup period for the model. Meteorological forcings, i.e., daily time series of precipitation (P) and Penman-Monteith reference evapotranspiration (ETo), were derived from the Integrated Multisatellite Retrievals for Global Precipitation Measurement (IMERG) dataset (Huffman et al. 2019b; a) and the gridded reference evapotranspiration dataset for Brazil based on machine learning (ETo-Brazil) (Althoff et al. 2020a; b), respectively. It is important to highlight that because the various climate indices and hydrological signatures (please refer to the following section) are derived from relatively short time series (12 years), it may occur that some regions experience drier or rainier years than the historical average. This could result in indices that do not accurately reflect the climate and water availability in a given region.

\section{Assessment of the water availability}

\section{Climate indices}

The climate is, in a large part, responsible for the processes occurring near the surface concerning precipitation and evaporation. Whether water remains on land or is returned to the atmosphere depends on the governing water and energy limitations (Knoben et al. 2018). Thus, four climate indices were adopted to characterize hydrologically relevant aspects of ottobasins: (i) the average annual moisture index $\left(\mathrm{I}_{\mathrm{m}}\right)$ (Knoben et al. 2018), (ii) moisture index seasonality $\left(\mathrm{I}_{\mathrm{m}, \mathrm{r}}\right)$ (Knoben et al. 2018), (iii) precipitation seasonality index (SI), and (iv) precipitation timing index (TI).

$I_{m}$ and $I_{m, r}$ give an overview of whether the watershed is generally water- or energy-limited, as well as how much this can change over the year. Knoben et al. (2018) used the $\mathrm{I}_{\mathrm{m}}$ and $I_{m, r}$ climate indices to define climate groups for over a thousand catchments worldwide. The authors showed that the climate classification based on these two indices along with the precipitation-as-snow, which does not apply for the Cerrado, was able to better group hydrologically similar catchments than a traditional climate classification. On the other hand, SI gives an idea of how rainfall is distributed over the year, and TI indicates whether rainfall and evapotranspiration peak in the same season. This gives us an idea of soil moisture dynamics and whether water has the opportunity to recharge the subsurface storage, or if it quickly evaporates from the surface storage. Gnann et al. (2020) also show that the individual terms obtained from the sine curves adjusted to meteorological forcings, which are also used to derive the SI and TI, show a strong relationship to certain catchments hydrological characteristics.

The average annual moisture index $\mathrm{I}_{\mathrm{m}}$ (Eq. 2) ranges from -1 to 1 , where -1 indicates the most arid conditions, i.e., water-limited conditions, and 1 indicates the most humid conditions, i.e., energy-limited conditions. The moisture index seasonality $I_{\mathrm{m}, \mathrm{r}}$ (Eq. 3) ranges from 0 to 2, where 0 indicates no seasonal changes in the water and energy budgets, whereas 2 indicates a climate shift between fully arid $\left(I_{\mathrm{m}}=-1\right)$ to fully humid $\left(I_{\mathrm{m}}=1\right)$ conditions within a year.

$\operatorname{MI}(t)=\left\{\begin{array}{cc}1-\frac{E_{\mathrm{m}}(t)}{P_{\mathrm{m}}(t)}, & P_{\mathrm{m}}(t)>E_{\mathrm{m}}(t) \\ 0, & P_{\mathrm{m}}(t)=E_{\mathrm{m}}(t) \\ \frac{P_{\mathrm{m}}(t)}{E_{\mathrm{m}}(t)}-1, & P_{\mathrm{m}}(t)<E_{\mathrm{m}}(t)\end{array}\right.$

$I_{\mathrm{m}}=\frac{1}{12} \sum_{t=1}^{t=12} \mathrm{MI}(t)$

$I_{\mathrm{m}, \mathrm{r}}=\max [\mathrm{MI}(1,2, \ldots 12)]-\min [\mathrm{MI}(1,2, \ldots 12]$

where $\mathrm{MI}(t)$ is the monthly moisture index (dimensionless), $E_{m}(t)$ is the mean monthly potential evaporation, $P_{m}(t)$ is the mean monthly precipitation, $t$ denotes the months from January to December (1 to 12 ), $\mathrm{I}_{\mathrm{m}}$ is the average annual moisture index, and $\mathrm{I}_{\mathrm{m}, \mathrm{r}}$ is the moisture index seasonality. Although $\mathrm{I}_{\mathrm{m}}$ and $\mathrm{I}_{\mathrm{m}, \mathrm{r}}$ rely on potential evaporation data, the reference evapotranspiration is closely related to the potential evaporation, and since the former is readily available in the HydroCerrado dataset, it was adopted instead.

The precipitation seasonality and timing indices, i.e., SI and TI, respectively, were derived from sine curves (Eqs. 4-5) representing annual precipitation and temperature cycles, respectively (Woods 2009). SI (Eq. 6) is a positive integer and indicates the amplitude of the precipitation sine curve concerning the mean precipitation; an SI value equal to 0 indicates no seasonality, whereas higher SI values indicate stronger seasonality. TI (Eq. 7) ranges from -1 to 1 , where -1 indicates a complete mismatch between precipitation and temperature peaks ( $\sim 6$ months), i.e., precipitation peaks occurring during the cold season, while 1 indicates 
that these peaks concurrently occur, i.e., precipitation peaks during the warm season. These variables summarize the precipitation amplitude and phase relative to the temperature. The reference evapotranspiration was also adopted instead of the temperature in these equations. This adaptation to the precipitation timing index should be favorable because the precipitation peak is then truly compared to the peak in the atmospheric demand.

$P(t)=\bar{P}\left[1+\delta_{\mathrm{P}} \sin \left(2 \pi\left(t-s_{\mathrm{P}}\right) / \tau\right)\right]$

$E(t)=\bar{E}\left[1+\delta_{\mathrm{E}} \sin \left(2 \pi\left(t-s_{\mathrm{E}}\right) / \tau\right)\right]$

$S I=\delta_{\mathrm{P}}$

$\mathrm{TI}=\operatorname{sign}\left(\delta_{\mathrm{P}}\right) \operatorname{sign}\left(\delta_{\mathrm{E}}\right) \cos \left(2 \pi\left(s_{\mathrm{P}}-s_{\mathrm{E}}\right) / \tau\right)$

where $P(t)$ and $E(t)$ are the daily time series of precipitation and reference evapotranspiration $\left(\mathrm{mm} \mathrm{day}^{-1}\right)$, respectively, $t$ is the time (days), $\bar{P}$ and $\bar{E}$ are the time-averaged precipitation and reference evapotranspiration, respectively, $\delta_{P}$ and $\delta_{E}$ are the seasonal amplitudes of the respective sine curves, $\tau$ is the duration of the seasonal cycle ( 365 days), and $s_{P}$ and $s_{E}$ are the precipitation and reference evapotranspiration phase shifts (days), respectively.

\section{Hydrological signatures}

Hydrological signatures have commonly been considered to classify basins and gain insights into their hydrological processes (Addor et al. 2018; McMillan 2020). This study adopts 4 signatures (Table 1) selected mainly to characterize the water availability concerning the flow distribution, event frequency, duration, and flow dynamics. Because basins of different areas exhibit streamflows at very different magnitudes, all flow-related variables are expressed in flow units relative to the respective basin area, i.e., $\mathrm{mm} \mathrm{day}^{-1}(\mathrm{~L}$ $\mathrm{m}^{-2}$ day $^{-1}$ ) instead of, for example, $\mathrm{m}^{3} \mathrm{day}^{-1}$. The use of $\mathrm{mm}$ day $^{-1}$ as the flow unit ensures water availability comparability among basins of different areas. A standardized flow unit for these hydrological signatures has also been applied in many studies (Addor et al. 2018; Almagro et al. 2020; Knoben et al. 2018).

Hydrological signatures related to the flow distribution were chosen to measure the average water availability and the availability under low-flow conditions. Additionally, $\mathrm{Q}_{95}$ is adopted as a reference by the ANA to grant water withdrawal permits (maximum allowance: $70 \%$ of $\mathrm{Q}_{95}$ based on which existing water permits are discounted), although the ANA applied the term $\mathrm{Q}_{95}$ to refer to the streamflow in volumetric flow units, i.e., in $\mathrm{m}^{3} \mathrm{~s}^{-1}$ instead of $\mathrm{mm} \mathrm{day}^{-1}$. The flow dynamics signature, BFI $[0,1]$, measures the proportion of the streamflow that is derived from subsurface sources. A higher BFI indicates a sustained streamflow during drought periods (Gustard et al. 1992). Signatures related to the event frequency and duration were also selected to provide insights into low-flow conditions. These signatures were calculated per year, and the average was determined as the yearly signatures.

\section{Risk classification}

Considering the importance of $\mathrm{Q}_{95}$ to grant water withdrawal permits, a risk classification analysis was proposed herein to categorize the severity of the pressure on the water availability in each month. The main contribution of this risk classification is the assessment of streamflow series regarding its distribution, i.e., the probability that the streamflow is lower than or equal to a certain flow percentile. First, daily flows were categorized according to the pressure severity on the water availability in river streams (Table 2). The risk classification was then averaged for each month. This analysis is important to detect those regions and periods with the

Table 1 Overview of the hydrological signatures selected in this study

\begin{tabular}{|c|c|c|c|}
\hline Signature & Abbreviation & Unit & Description \\
\hline \multicolumn{4}{|l|}{ Flow distribution } \\
\hline Mean flow & $\overline{\mathrm{Q}}$ & $\mathrm{mm} \mathrm{day}^{-1}$ & Mean flow during the period \\
\hline Flow percentile & $\mathrm{Q}_{95}$ & $\mathrm{~mm} \mathrm{day}^{-1}$ & Flow exceedance percentile from the flow duration curve \\
\hline \multicolumn{4}{|c|}{ Event frequency and duration } \\
\hline Low-flow duration & $\mathrm{Q}_{\mathrm{LD}}$ & Days & $\begin{array}{l}\text { Average duration of consecutive daily low-flow events* } \\
\text { (Westerberg and McMillan 2015) }\end{array}$ \\
\hline \multicolumn{4}{|l|}{ Flow dynamics } \\
\hline Baseflow index & BFI & - & $\begin{array}{l}\text { Contribution of the baseflow to the total streamflow } \\
\text { (Gustard et al. 1992) }\end{array}$ \\
\hline
\end{tabular}

\footnotetext{
*In Westerbeg and McMillan (2015), low-flow events are days when the flow is lower than $0.2 * \overline{\mathrm{Q}}$. Here, low-flow events are considered days
} when the flow is lower than $\mathrm{Q}_{80}$, i.e., the 80th percentile of the daily flow 
Table 2 Classes of the risk severity according to the water availability

\begin{tabular}{ll}
\hline Risk classification & Water availability \\
\hline 1-Very low & $\mathrm{Q}>\mathrm{Q}_{80}$ \\
2-Low & $\mathrm{Q}_{90}<\mathrm{Q} \leq \mathrm{Q}_{80}$ \\
3-Moderate & $\mathrm{Q}_{95}<\mathrm{Q} \leq \mathrm{Q}_{90}$ \\
4-High & $\mathrm{Q} \leq \mathrm{Q}_{95}$ \\
\hline
\end{tabular}

highest pressure on surface water resources. Although certain definitions of risk and water security have been applied to describe the potential to impose harmful states for humans or the environment (Hall and Borgomeo 2013), this study considered the risk as the susceptibility to low-flow conditions, which occurred because information concerning the water demand is scarce, and the hydrological signature $\left(Q_{95}\right)$ used as a reference to grant water permits is also based on the flow distribution.

\section{Potential for sustainable water use increase}

The ratio between $\mathrm{Q}_{95}$ and $\overline{\mathrm{Q}}\left(\mathrm{Q}_{95} / \mathrm{Q}\right)$ is proposed here to be applied as a proxy of the potential to increase the sustainable water use. $Q$ provides information on the average water availability in ottobasins, whereas $\mathrm{Q}_{95}$ is the reference signature considered to grant water withdrawal permits and the flow likely encountered during drought periods. Thus,
$\mathrm{Q}_{95} / \mathrm{Q}$ provides information on the regularization capacity of ottobasins and could be regarded as the relative water availability. Lower ratios indicate that there exists a greater potential for local water storage, e.g., the use of on-farm dams or large dams to accumulate excess runoff and the provision of water during periods of drought, i.e., increasing the effective water availability.

\section{Results and discussion}

\section{Hydroclimatic characterization}

To better showcase how the above climate indices were obtained and to characterize the different regions across the Cerrado, Fig. 3 shows the time series of the meteorological forcings and the climate indices for an arbitrary ottoba$\sin (\mathrm{ID}=74,929$, longitude $=-45.07$, latitude $=-9.09)$. The sine curves are approximations of the meteorological forcing seasonality and reveal the mismatch between the precipitation and reference evapotranspiration peaks. The timing index ( $\mathrm{TI}=-0.544)$ indicates a mismatch of approximately 125 days (solving Eq. 7 for $s_{P}-s_{E}$ : $s_{P}-s_{E}=\cos ^{-1}(-0.544) 2 \pi / 365=124.6$ days $)$ between the precipitation and reference evapotranspiration peaks. The seasonality index $(\mathrm{SI}=1.178)$ indicates a strong seasonality,

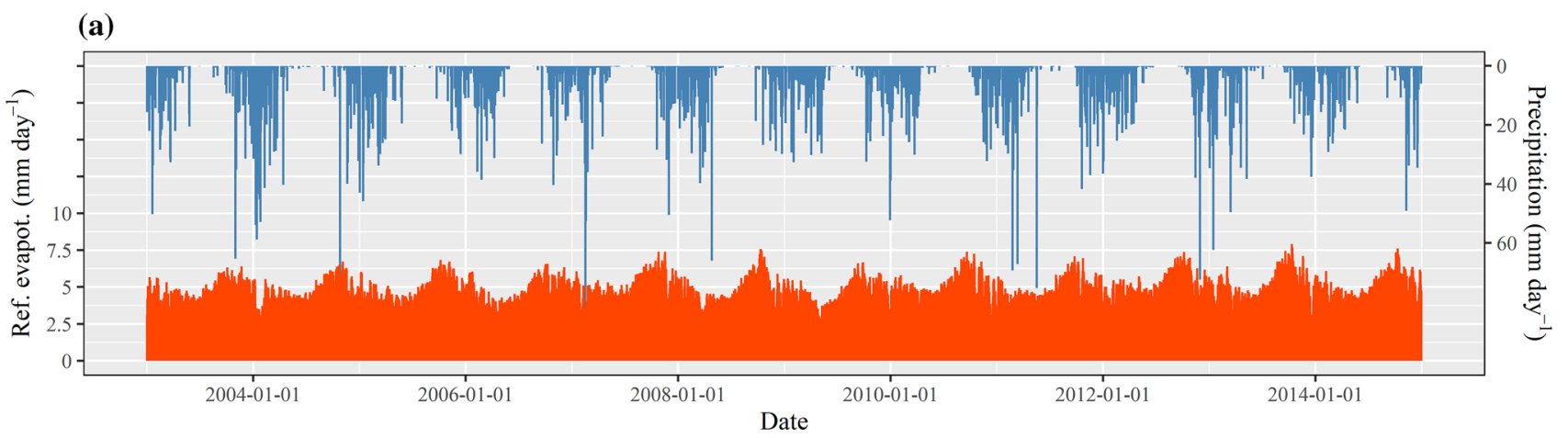

(b)

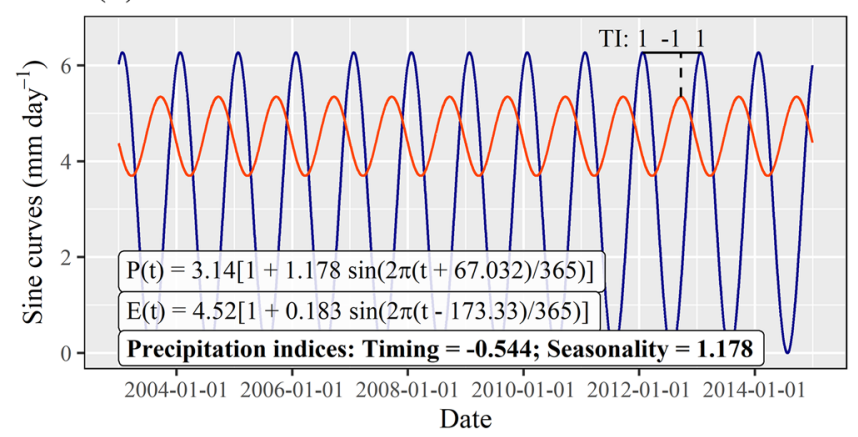

(c)

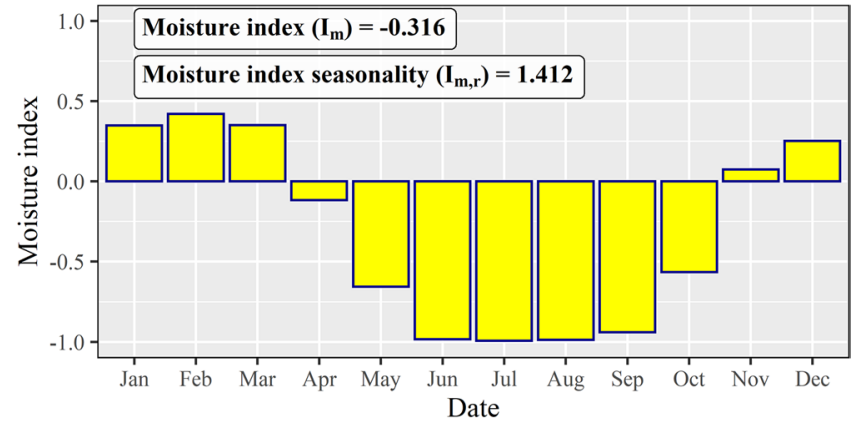

Fig. 3 Time series of a precipitation and reference evapotranspiration, $\mathbf{b}$ their respective sine curves, and $\mathbf{c}$ monthly moisture index for an arbitrary ottobasin $(\mathrm{ID}=74,929)$ 
with an amplitude larger than that of the mean precipitation (3.14 $\left.\mathrm{mm} \mathrm{day}^{-1}\right)$. The negative moisture index $\left(I_{\mathrm{m}}=-0.316\right)$ indicates a condition of aridity where the monthly potential evapotranspiration is generally higher than the precipitation. The moisture index seasonality above $1\left(\mathrm{I}_{\mathrm{m}, \mathrm{r}}=1.412\right)$ indicates that the monthly climate conditions range from energylimited to water-limited conditions throughout the year.

The context of the above climate indices for all of the level 5 Cerrado ottobasins is shown in Fig. 4. The Cerrado ottobasins are predominantly water-limited basins (negative $I_{m}$ ), and their seasonality is remarkably high, as indicated by the $\mathrm{I}_{\mathrm{m}, \mathrm{r}}$ values higher than 1.4 for most of the Cerrado. This is an outcome of its high energy input throughout the year and its two well-defined seasons. These climate indices provide evidence, however, of the transition to different climates. For example, the eastern Cerrado exhibits the most arid conditions (lower $I_{\mathrm{m}}$ ) and a low seasonality (low $\left.\mathrm{I}_{\mathrm{m}, \mathrm{r}}\right)$, characterizing the transition to a semiarid climate. The southern Cerrado contains ottobasins with lower water limitations or even a certain energy limitation and, with a lower moisture index seasonality, characterize the transition to a humid subtropical climate. The western Cerrado borders the Amazon and characterizes the transition to a tropical monsoon climate.

TI reveals that the precipitation peaks along with the atmospheric demand for water in the south/southeastern regions (positive values), while the precipitation peaks during the opposite periods to those when the evapotranspiration peaks in the northern region (negative values). The central Cerrado exhibits a smaller mismatch between the precipitation and evapotranspiration peaks. SI indicates a strong seasonality in the precipitation $(\mathrm{SI}>1.0)$ for most of the Cerrado, whereas the southern Cerrado attains values closer to 0 in the transition to a humid subtropical climate. The lower SI values in the southern region indicate that rainfall is better distributed throughout the year in these ottobasins.

Figure 5 shows a summary of the hydrological signatures for the same arbitrary ottobasin depicted in Fig. 3. A significant portion of the streamflow originates from shallow or subsurface flows $(\mathrm{BFI}=0.872)$, indicating that most of the precipitation infiltrates and does not contribute to surface runoff. The mean flow ( $\left.\overline{\mathrm{Q}}=0.313 \mathrm{~mm} \mathrm{day}^{-1}\right)$ is approximately $80 \%$ higher than the $95^{\text {th }}$ percentile of the daily flow $\left(Q_{95}=0.173 \mathrm{~mm} \mathrm{day}^{-1}\right)$, which is adopted as a reference to grant water withdrawal permits. This demonstrates that there are opportunities to increase the sustainable water use and the availability during drought periods through storage and rainwater harvesting techniques (further discussed in Sect. 3.3). The above flow considers a daily low-flow event $\left(Q_{80}=0.202 \mathrm{~mm} \mathrm{day}^{-1}\right)$ approximately $17 \%$ higher than $\mathrm{Q}_{95}$. Despite not detecting low-flow events each year, e.g., from 2004 to 2007, its average duration is 57.7 days and increases up to 138 and 141 days in 2010 and 2014, respectively.

The hydrological signatures (Fig. 6) reveal a remarkably higher water availability, in terms of $\bar{Q}$, at the transition between the Cerrado and the Amazon biomes (western Cerrado). However, this does not necessarily indicate a higher $\mathrm{Q}_{95}$ value. The ottobasins in this region are characterized by a low water limitation and a higher annual precipitation. A considerably higher water availability is also observed in the southern Cerrado, especially with respect to $Q_{95}$. Due to their proximity to regions characterized by a transition to a
Fig. 4 Climate indices for the level 5 ottobasins. $\mathrm{I}_{\mathrm{m}}=$ moisture index, $I_{\mathrm{m}, \mathrm{r}}=$ moisture index seasonality, $\mathrm{SI}=$ precipitation seasonality index, and $\mathrm{TI}=$ precipitation timing index
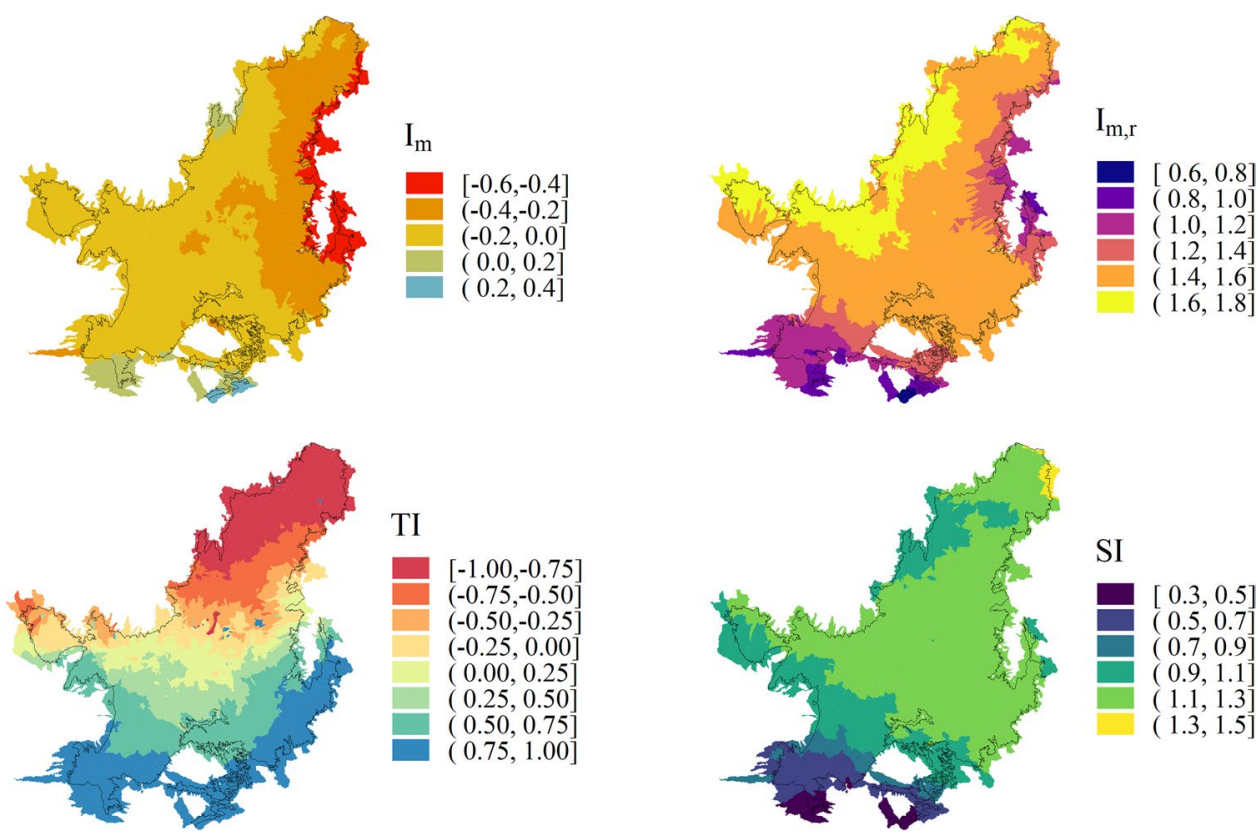

TI

$[-1.00,-0.75]$

$(-0.75,-0.50]$

$(-0.50,-0.25]$

$(-0.25,0.00]$

$(0.00,0.25]$

$(0.25,0.50$

$(0.50,0.75$

$(0.75,1.00]$

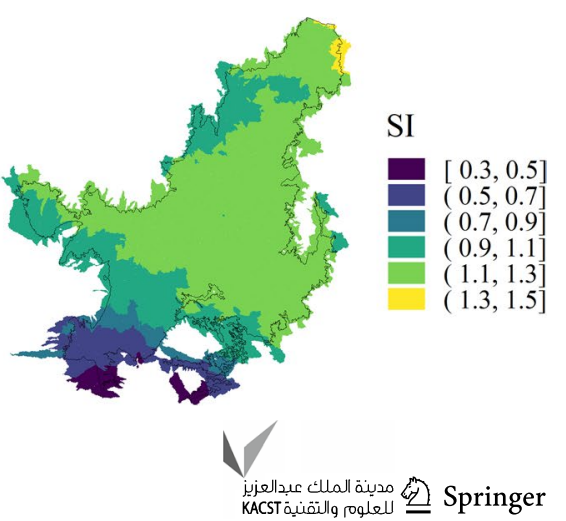



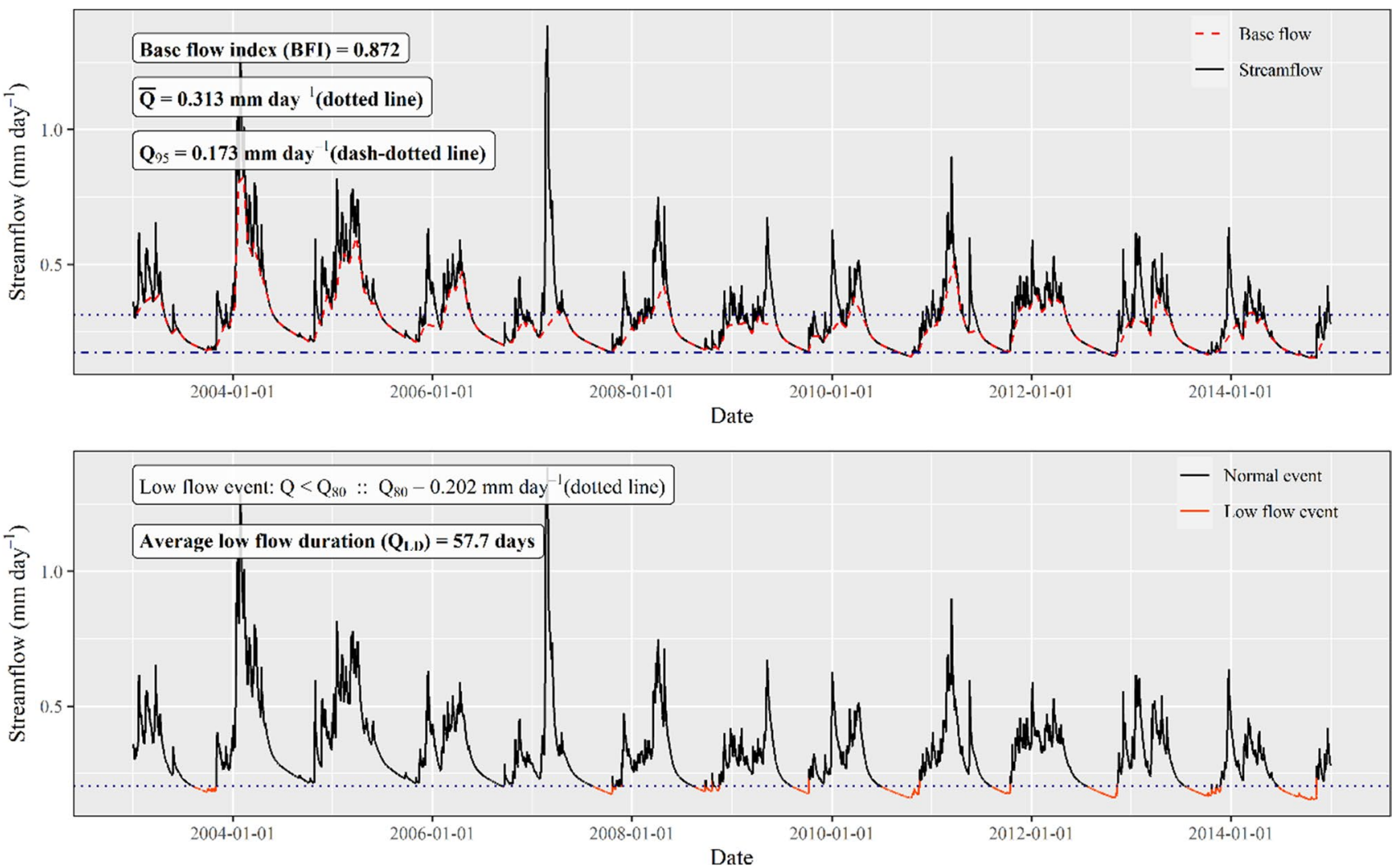

Fig. 5 Time series of the streamflow and various hydrological signatures for an arbitrary ottobasin $(\mathrm{ID}=74,929)$. $Q=$ mean flow, $Q_{95}=95$ th percentile of the daily flow, $\mathrm{BFI}=$ baseflow index, and $\mathrm{Q}_{\mathrm{LD}}=$ low-flow event $\left(\mathrm{Q}<\mathrm{Q}_{80}\right)$ duration

Fig. 6 Hydrological signatures of the level 5 ottobasins. $\mathrm{Q}=$ mean flow, $\mathrm{Q}_{95}=95$ th percentile of the daily flow, $\mathrm{BFI}=$ baseflow index, and $\mathrm{Q}_{\mathrm{LD}}=$ low-flow event $\left(\mathrm{Q}<\mathrm{Q}_{80}\right)$ duration


$\mathrm{Q}_{95}\left(\mathrm{~mm} \mathrm{day}^{-1}\right)$

$[0.0,0.1]$

$(0.1,0.2]$

$(0.2,0.4]$

$(0.4,0.6]$

$(0.6,1.0]$

$(1.0,1.4]$

$(1.4,2.0]$

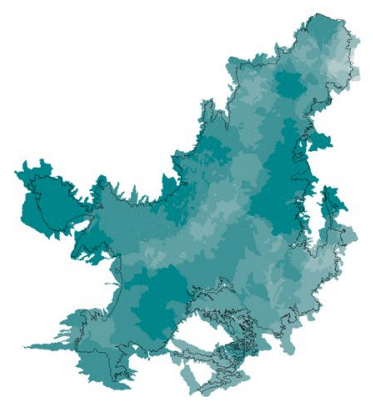

BFI

$[0.2,0.3]$

$(0.3,0.4]$

$(0.4,0.5$

$(0.5,0.6$

$(0.6,0.7]$

$(0.7,0.8$

$(0.8,0.9]$

$(0.9,1.0]$

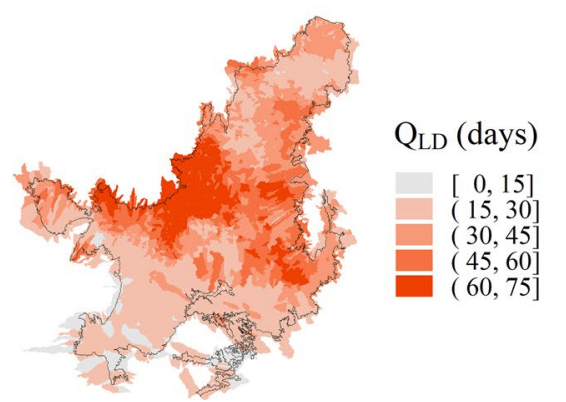


semiarid climate, the eastern and northern Cerrado regions are characterized by a lower overall water availability.

Representing flow dynamics, BFI indicates higher values in regions with higher $\mathrm{Q}_{95}$ values. This occurs because a higher BFI indicates that most of the precipitation infiltrates and runoff is composed mostly of subsurface runoff and baseflow, i.e., the flow is better sustained during drought periods. Regarding the event frequency, considering events when the daily flow is lower than $\mathrm{Q}_{80}$ leads to an annual frequency of approximately $20 \%$ of the daily flow observations, i.e., 73 days. However, it is important to assess the duration of these events and whether they are concentrated during the same period. This information is important to highlight regions where drier years could exert further pressure on their water availability and result in restrictions during long periods. For example, there are several ottobasins in the middle portion of the Cerrado, especially in the western region, with a considerable duration of low-flow events. In these regions, the periods when the daily flows are below $\mathrm{Q}_{80}$ last for nearly or longer than two months. This can be attributed to the high seasonality in the regional climate $\left(\mathrm{I}_{\mathrm{m}, \mathrm{r}}\right.$, and SI, as shown in Fig. 4). In contrast, despite a frequency of $\sim 73$ days of their low-flow events each year, most of the northern and southern regions indicate that these events last between 15 and 30 days on average. In the southern region, this is attributed to a better rainfall distribution throughout the year, which results in closer values in the lower tail of the daily flow cumulative distribution function (CDF), e.g., close values of the 80th and 95th percentiles of the daily flow. In contrast, the northern region exhibits more arid conditions, which may also result in similar values in the lower tail of the CDF. In this case, however, the values are closer to 0 . When these values are more similar, it is easy for small perturbations in the streamflow to interrupt dry spells, i.e., the permanence of low-flow conditions is affected.

\section{Risk assessment}

Risk assessment results are shown in Fig. 7 for the same arbitrary ottobasin (ID $=74,929)$, where the daily flows are classified according to their risk of imposing pressure on the water availability (Table 2 ). The percentage of the occurrence plot is based on the risk classification of the flow events in a given month considering the entire time series, e.g., the percentage of the time the flow is below $\mathrm{Q}_{95}$ in all months of September from 2003 to 2014. In this particular ottobasin, the occurrence of events characterized by a risk higher than very low increases from June until September, thereby exhibiting a high occurrence of low-risk (29.4\%), moderate-risk (25.0\%), and high-risk (20.6\%) events. Only
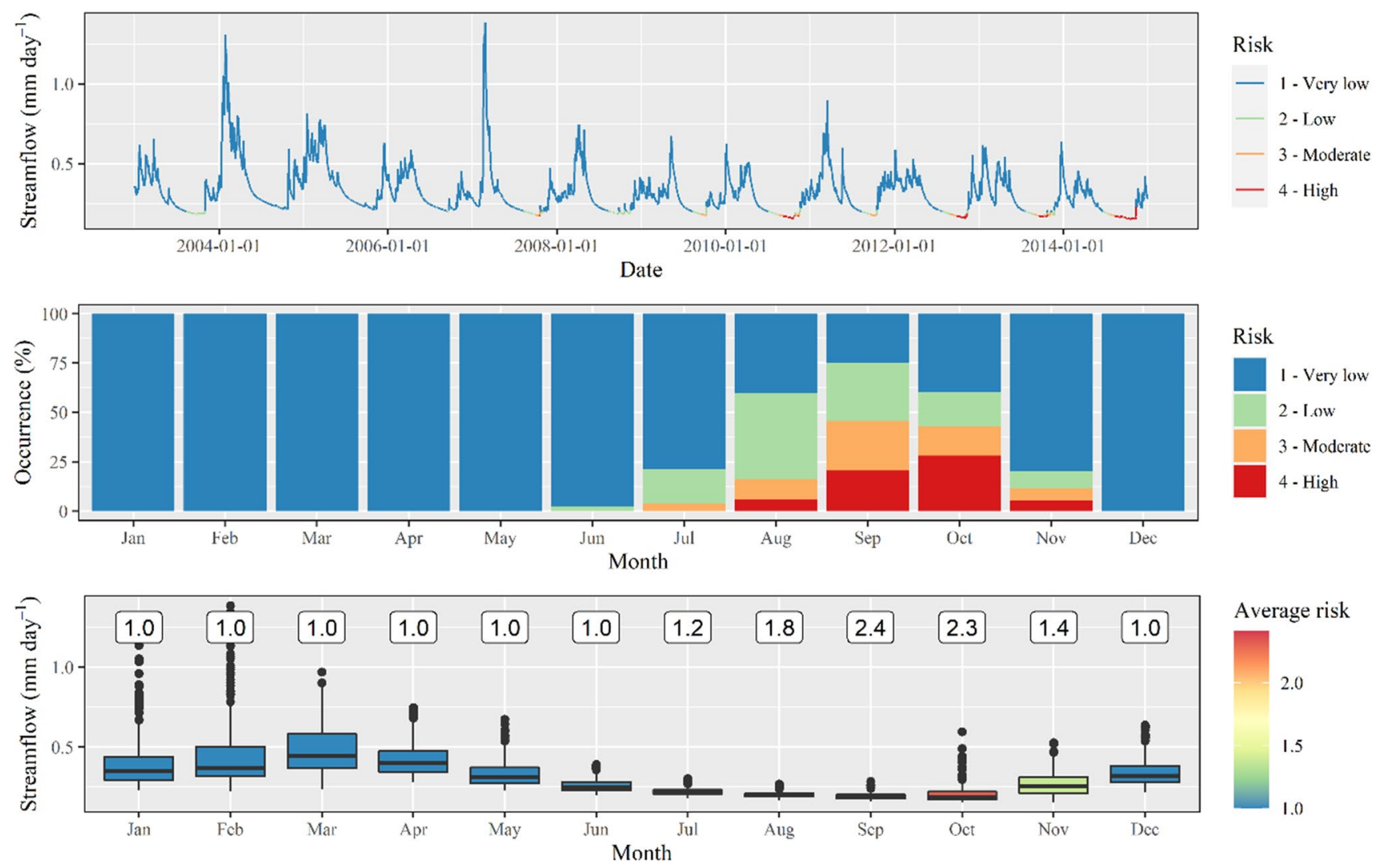

Average risk

Fig. 7 Risk assessment of the pressure severity on the water availability in an arbitrary ottobasin $(\mathrm{ID}=74,929)$ 
on rare occasions does June contain low-risk events, i.e., indicating a low pressure on the water availability.

The final assessment is based on averaging the risks in each month over the entire study period $(2003$ - 2014), which is labeled for each month above the boxplot and is also represented by the boxplot color. The average risk of an increased pressure on the water availability in September ranged from a low to moderate risk (average risk $=2.4$ ). Despite a lower average risk (2.3), October exhibited the highest occurrence of a high risk (28.2\%) of an increased pressure on the water availability. The occurrence of a high risk in October can be attributed to the uncertainty in rainfall occurrence in the transition between the dry and wet seasons. When the dry season lasts until late October, the flow in river streams continues to decrease, and the pressure on water resources increases.

The risk assessment is summarized for the entire Cerrado in Fig. 8 by reporting the month classified with the highest risk, i.e., the highest average risk to the water availability, and the risk associated with it. As part of the tropics in the Southern Hemisphere, the Cerrado experiences a higher energy input from August to December, and its wet season begins in October and lasts until March or early April (Althoff et al. 2021a). This justifies September and October as being the months with the highest risk across most of the Cerrado. In contrast, the wet season is mainly concentrated from February to April in the northern Cerrado, mismatching the period of a high energy input (negative TI values, as shown in Fig. 4). Thus, the period from November to January is characterized as the period of the highest risk in the northern region. Overall, the period of the highest risk generally characterizes the beginning of the wet season. This indicates that agricultural activities are jeopardized not only by the uncertain precipitation distribution in time and space but also by the decreased irrigation due to the lower availability in river streams.

The risk is reportedly higher in the central region (from 2.5 to 3.5 ), matching those regions with the highest moisture index seasonality (Fig. 4). Some fragmented areas exhibit an average risk above 3 , i.e., a moderate to high risk, whereas in most of the Cerrado, the average risk in these months ranges from a low to moderate risk (2.5 to 3.0) or at least a low risk in the optimistic cases (2.0 to 2.5). Only a few regions exhibit a risk varying between a very low and low risk (1.5 to 2.0). The severity of the pressure on the water availability can be explained mainly by the strong seasonality in the moisture index (Fig. 4). The high moisture index seasonality indicates that one of the seasons experiences a much higher energy input than that of water, resulting in long drought periods and allowing for a continuous decrease in streamflow. Some of these regions also match those regions where low-flow events last longer (Fig. 6).

\section{Can the sustainable water use be increased?}

It is evident that certain regions attain a higher average water availability than do other regions (the mean streamflow, as shown in Fig. 6). However, due to their seasonality, the hydrological signatures applied as a reference to grant water withdrawal permits $\left(\mathrm{Q}_{95}\right)$ can be much lower than the mean water availability $(\mathrm{Q})$. Thus, the $\mathrm{Q}_{95} / \mathrm{Q}$ ratio (Fig. 9) can be adopted to assess the temporal flow distribution and
Fig. 8 In each ottobasin, the month represents the highest average risk of an increased pressure on the water availability and the average risk associated with it
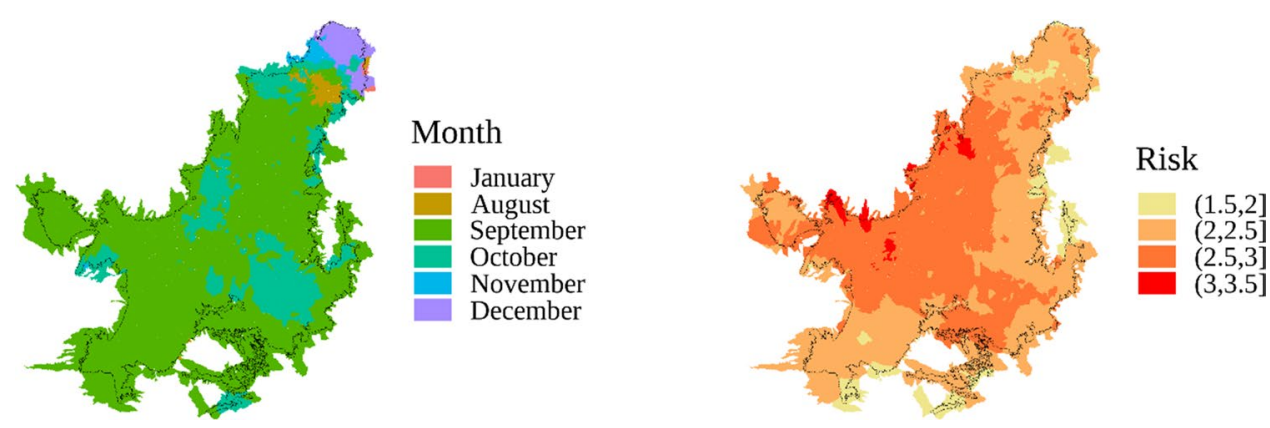

Fig. 9 Spatial distribution of the ratio between hydrological signatures $\mathrm{Q}_{95}$ and $\mathrm{Q}$ for each ottobasin and center pivots (data source: ANA, 2019) in the Cerrado. $\mathrm{Q}=$ mean flow, and Q95 = 95th percentile of the daily flow. The center pivot is used here to represent the irrigation water demand

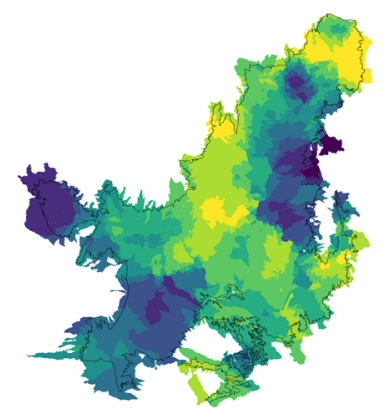



$(1.5,2]$

$2,2.5$

$(2.5,3]$

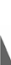


the potential for local storage increase (i.e., the lower the ratio is, the poorer the flow distribution over time, which indicates a higher potential to use local storage as an adaptation measure to increase the water availability). Lower ratios indicate higher chances of success for water resource management strategies such as limited in situ storage. Similar techniques have been widely documented to increase the regional water sustainability, increase resilience to climate change, and decrease conflicts over water use (Boelee et al. 2013; Iglesias and Garrote 2015; Malveira et al. 2012; Rodrigues et al. 2012). In summary, lower $\mathrm{Q}_{95} / \mathrm{Q}$ ratios also indicate that local storage exhibits a higher potential to support sustainable irrigation expansion, i.e., expansion of irrigation activities without depleting freshwater stocks or loss of environmental flows (Rosa et al. 2020).

There is an important dynamic, in terms of energy- or water-limited watersheds, between the moisture index, its seasonality, the precipitation timing index, and the $\mathrm{Q}_{95} / \mathrm{Q}$ ratio (Figs. 4 and 9). In general, both very water-limited $\left(\mathrm{I}_{\mathrm{m}}<-0.4\right)$ and energy-limited (positive $\mathrm{I}_{\mathrm{m}}$ values) watersheds tend to attain a lower climate seasonality, i.e., lower $\mathrm{I}_{\mathrm{m}, \mathrm{r}}$ values and, therefore, higher $\mathrm{Q}_{95} / \mathrm{Q}$ ratios. For example, the soil moisture increases in the eastern Cerrado (very water-limited) correlate better with/result in higher evaporation rates instead of runoff. This indicates that the precipitation in the eastern Cerrado generates smaller responses in runoff (high BFI values, as shown in Fig. 6). In contrast, the western and southwestern Cerrado regions, characterized by lower energy limitations, exhibit a better precipitation distribution throughout the year (TI closer to 0), resulting in higher infiltration, soil moisture, and year-round runoff (high BFI). This results in the runoff correlating better with the soil moisture than with the precipitation. Similar correlations between the soil moisture, precipitation, evaporation, and runoff have been well documented in previous studies, e.g., Ghajarnia et al. (2020a) and Ghajarnia et al. (2020b). Thus, the $\mathrm{Q}_{95} / \mathrm{Q}$ ratios were generally positively correlated with BFI and negatively correlated with the climate seasonality $\left(\mathrm{I}_{\mathrm{m}, \mathrm{r}}\right)$. The eastern Cerrado, despite exhibiting high $\mathrm{I}_{\mathrm{m}, \mathrm{r}}$ values, attained higher $\mathrm{Q}_{95} / \mathrm{Q}$ ratios. This can be attributed to the high BFI values and, therefore, the lower direct contribution of precipitation to runoff. In between, the central Cerrado, which attains lower degrees of limitations concerning either water or energy, exhibits higher $I_{m, r}$ values and lower $\mathrm{Q}_{95} / \mathrm{Q}$ ratios. The northern Cerrado contains very waterlimited ottobasins, but the wet period opposes the period of higher evaporative demands (a negative timing index, as shown in Fig. 4). This increases the opportunity for water infiltrated into the soil to reach river streams during the wet season and results in an increased mean flow. However, since the area is characterized as a very water-limited region, it attains a much lower availability during the dry season (low $\mathrm{Q}_{95}$ ) and, therefore, low $\mathrm{Q}_{95} / \mathrm{Q}$ ratios.
As opposed to small farm reservoirs, the construction of large dams could regularize the flow during periods longer than a year. However, both small and large dams could notably increase water losses due to evaporation (Althoff et al. 2020c; Pereira et al. 2009). More technically sound alternatives could help prevent such losses and simultaneously produce energy. For example, Cavusoglu et al. (2017) reported water evaporation as a reliable source of renewable energy that could help reduce surface water evaporation. Solar panels have also been applied to cover open-water reservoirs and irrigation canals and decreased evaporative losses and an increased efficiency have been reported for these photovoltaic systems (Youssef and Khodzinskaya 2019). The northern Cerrado, which experiences a more arid climate, should require a greater effort to improve the sustainable use of surface water. Farm-level reservoirs should preferably be deeper than wider (Althoff et al. 2020c). Alternatively, underground reservoirs should be built to restrict subsurface runoff and extend the period when the soil moisture level is higher.

Regions with a higher relative water availability $\left(\mathrm{Q}_{95} / \mathrm{Q}\right)$ should be carefully assessed. For example, western Bahia state (eastern Cerrado) exhibits high $\mathrm{Q}_{95} / \mathrm{Q}$ ratios but a low water availability, thus requiring attention. A low water availability ( $\mathrm{Q}$ and $\mathrm{Q}_{95}$ ) and high demand, which is represented here by a center pivot, result in conflicts over water use that have been widely documented (Pousa et al. 2019). Alternatively, farmers have begun exploiting options other than surface water. The increasing agribusiness activities in the region have led, however, to intensified groundwater withdrawal and unsustainable exploitation, as documented by the severe drawdown in groundwater levels (Marques et al. 2020).

Overall, the central Cerrado reveals more opportunities to improve sustainable surface water exploitation through local water storage, especially in its central area (low $\mathrm{Q}_{95} / \mathrm{Q}$ ratios). The western and southern areas, however, already exhibit a higher water availability and a higher baseflow index in some regions. Figure 6 also shows the center pivots of the irrigation systems in the Cerrado as of 2017 (Althoff and Rodrigues 2019; ANA 2019). The high concentration of center pivots in the central-southern region can be partially attributed to the favorable conditions during the cropping periods, i.e., the positive timing of the precipitation index. Higher precipitation during periods when the climate is favorable for crop development results in a higher productivity and profitability. Profitability often translates into technification, e.g., the use of irrigation systems. Althoff and Rodrigues (2019) also highlighted that a trend of smaller center pivots $(<50$ ha) has occurred over the last decade. This likely indicates that smallholders are also becoming more technically well developed and benefit from irrigation systems to guarantee their productivity/profitability when

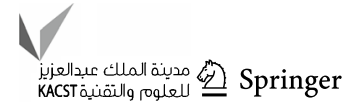


precipitation is uncertain. Moreover, there is still a large area where irrigation can be expanded in the Cerrado with a lower risk due to the existing potential to increase the water availability through local small-scale storage, i.e., regions with a low relative water availability (Fig. 9) and high mean streamflow (Fig. 6). In these regions, the improvement of water resource management could support agricultural development when crop water requirements are higher than the natural supply (green water scarcity) (Rosa et al. 2020). In regions already facing conflicts (blue water scarcity), the best alternative could be the adoption of deficit irrigation techniques in years with a lower availability (Geerts and Raes 2009).

Moreover, we would like to highlight one important limitation of this study. The study was developed considering the regionalization of parameters based on a hydrological model calibrated against a relatively short and recent streamflow series. This indicates that the hydrological signatures were not obtained from natural streamflow series but rather from series considering the already existing water withdrawals upstream. This may be the case in some regions where an amount of water larger than $\mathrm{Q}_{95}$, as reported in this study, could be withdrawn without drying out the river level. Thus, it is important to also consider the ongoing water grants in each ottobasin to formulate more informed decisions. In addition, if anomalies are detected during the short period considered in this study, this could also cause a lower reliability of the derived indices. Last, the risk assessment approach could be improved in future studies by considering current water grants and demands.

\section{Conclusions}

The high seasonality of the moisture index agrees with former climate classifications that define the Cerrado climate as a tropical savannah climate, i.e., with two well-defined seasons. Transition between the Cerrado and other biomes is revealed to be the determining factor in its climate characteristics, e.g., a lower moisture index in the northeastern Cerrado, bordering the Caatinga, or a higher moisture index in the southern Cerrado, bordering the Atlantic rainforest. The water availability (mean streamflow) is generally higher in the western and southern regions. Higher baseflow indices highlight, in some regions, the low contribution of rainfall to runoff, whereas regions with a lower baseflow index tend to be more responsive to rainfall.

The hydrological signature related to the low-flow event duration emphasizes the central to eastern regions as more prone to long-lasting dry periods. In contrast, low-flow events tend to exhibit shorter durations in the southern Cerrado. Overall, the water resources in the Cerrado occur under the highest pressure from September to October, whereas the pressure shifts to November, December, and January in the northern Cerrado. The average risk is also higher in the same regions that attain a high moisture index seasonality. These regions exhibit a mean flow that is much higher than the minimum flow adopted as a reference to grant water permits, and given the high climate seasonality across the Cerrado, these regions could benefit from, for example, local storage of excess runoff and water resource management strategies, such as shared water resource management.

Funding This study was financed in part by the Coordenação de Aperfeiçoamento de Pessoal de Nível Superior (CAPES-In English: Coordination of Improvement of Higher Education Personnel) - Finance code 001, and by the Conselho Nacional de Desenvolvimento Científico e Tecnológico (CNPQ - In English: National Council for Scientific and Technological Development) - Grant number 142273/2019-8.

Code availability The code developed in this study can be made available by the corresponding author upon request.

Data availability All data used and code generated during the study are available from the corresponding author upon request. The data set compiled in this study, HydroCerrado, is available at the following online repository: https://github. com/daniel-althoff/HydroCerrado/.

\section{Declarations}

Conflict of interest The authors declare that they have no conflict of interest.

Ethics approval Animal research: Does not apply. Consent to participate: Does not apply. Consent to publish: Does not apply. All authors have consented to participate and publish the manuscript.

Plant reproducibility Does not apply.

Open Access This article is licensed under a Creative Commons Attribution 4.0 International License, which permits use, sharing, adaptation, distribution and reproduction in any medium or format, as long as you give appropriate credit to the original author(s) and the source, provide a link to the Creative Commons licence, and indicate if changes were made. The images or other third party material in this article are included in the article's Creative Commons licence, unless indicated otherwise in a credit line to the material. If material is not included in the article's Creative Commons licence and your intended use is not permitted by statutory regulation or exceeds the permitted use, you will need to obtain permission directly from the copyright holder. To view a copy of this licence, visit http://creativecommons.org/licenses/by/4.0/. 


\section{References}

Addor N, Nearing G, Prieto C, Newman AJ, Vine NL, and Clark MP. (2018) Selection of hydrological signatures for large-sample hydrology. EarthArXiv

Almagro A, Oliveira PTS., Meira Neto AA., Roy T, and Troch P (2020) CABra: a novel large-sample dataset for Brazilian catchments. Hydrology and Earth System Sciences Discussions, Copernicus $\mathrm{GmbH}, 1-40$

Althoff D, Rodrigues LN (2019) The expansion of center-pivot irrigation in the Cerrado biome. IRRIGA, Inovagri Special Edition 1(1):56-61

Althoff D, Dias SHB, Filgueiras R, Rodrigues LN (2020) ETo-Brazil: a daily gridded reference evapotranspiration data set for Brazil - repository. Mendeley Data V3. https://doi.org/10.1029/2020W R027562

Althoff D, Dias SHB, Filgueiras R, Rodrigues LN (2020) ETo-Brazil: a daily gridded reference evapotranspiration data set for Brazil (2000-2018). Water Resources Research. https://doi.org/ 10.1029/2020WR027562

Althoff D, Rodrigues LN, da Silva DD (2020c) Impacts of climate change on the evaporation and availability of water in small reservoirs in the Brazilian savannah. Clim Change 159(2):215-232

Althoff D, Bazame HC, Filgueiras R, Rodrigues LN (2021) Assessing rainfall spatial variability in the Brazilian savanna region with TMPA rainfall dataset. J South Am Earth Sci 111:103482

Althoff D, Rodrigues LN, and Silva DD. da. (2021b) HydroCerrado. Github repository, <https://github.com/daniel-althoff/ HydroCerrado/>

Althoff D, Rodrigues LN, and Silva DD da. (2021c). Predicting Runoff Series in Ungauged Basins of the Brazilian Cerrado Biome, submitted.

Alvares CA, Stape JL, Sentelhas PC, de MoraesGonçalves JL, Sparovek G (2013) Köppen's climate classification map for Brazil. Meteorol Z 22(6):711-728

ANA. (2014). Subsídios para a discussão da compatibilização da geração de energia hidrelétrica com expansão da agricultura irrigada na bacia do rio São Marcos. Agência Nacional de Águas, Brasília - DF, Brazil, 64

ANA. (2019). Levantamento da agricultura irrigada por pivôs centrais no Brasil (1985-2017). Agência Nacional de Águas, Embrapa Milho e Sorgo, Brasília - DF, Brazil, 47.

ANA. (2020). Portal de Metadados Geoespaciais. Agência Nacional de Águas (ANA).

Boelee E, Yohannes M, Poda J-N, McCartney M, Cecchi P, Kibret S, Hagos F, Laamrani H (2013) Options for water storage and rainwater harvesting to improve health and resilience against climate change in Africa. Reg Environ Change 13(3):509-519

Cavusoglu A-H, Chen X, Gentine P, Sahin O (2017) Potential for natural evaporation as a reliable renewable energy resource. Nat Commun 8(1):1-9

Chou SC, Lyra A, Mourão C, Dereczynski C, Pilotto I, Gomes J, Bustamante J, Tavares P, Silva A, Rodrigues D, Campos D, Chagas D, Sueiro G, Siqueira G, Marengo J (2014) Assessment of climate change over South America under RCP 4.5 and 8.5 downscaling scenarios. Am J Clim Chang 03(05):512-527

Costa MH, Pires GF (2010) Effects of Amazon and Central Brazil deforestation scenarios on the duration of the dry season in the arc of deforestation. Int J Climatol 30(13):1970-1979

de Oliveira VA, de Mello CR, Viola MR, Srinivasan R (2017) Assessment of climate change impacts on streamflow and hydropower potential in the headwater region of the Grande river basin, Southeastern Brazil. Int J Climatol 37(15):5005-5023
FEALQ. (2014). Análise territorial para o desenvolvimento da agricultura irrigada no Brasil. Fundação de Estudos Agrários Luiz de Queiroz, Piracicaba, SP, Brazil, 215.

Furnans, J., and Olivera, F. (2001). "Watershed Topology: The Pfafstetter System." 2001 User Conference Proceedings.

Geerts S, Raes D (2009) Deficit irrigation as an on-farm strategy to maximize crop water productivity in dry areas. Agric Water Manag 96(9):1275-1284

Ghajarnia, N., Kalantari, Z., and Destouni, G. (2020a). Data-driven worldwide quantification of large-scale hydroclimatic co-variation patterns and comparison with reanalysis and Earth System modeling. preprint, Hydrology.

Ghajarnia N, Kalantari Z, Orth R, Destouni G (2020b) Close covariation between soil moisture and runoff emerging from multi-catchment data across Europe. Sci Reports, Nature Pub Group 10(1):4817

Gnann SJ, Howden NJK, Woods RA (2020) Hydrological signatures describing the translation of climate seasonality into streamflow seasonality. Hydrol Earth Syst Sci, Copernicus GmbH 24(2):561-580

Gupta HV, Kling H, Yilmaz KK, Martinez GF (2009) Decomposition of the mean squared error and NSE performance criteria: Implications for improving hydrological modelling. J Hydrol 377(1):80-91

Gustard, A., Bullock, A., and Dixon, J. M. (1992). Low flow estimation in the United Kingdom. Institute of Hydrology.

Hall J, Borgomeo E (2013) Risk-based principles for defining and managing water security. Phil Trans R Soc A 371(2002):20120407

He X, Wada Y, Wanders N, Sheffield J (2017) Intensification of hydrological drought in California by human water management. Geophys Res Lett 44(4):1777-1785

Hosono A, Rocha CMC. da, and Hongo Y (2016) Development for Sustainable Agriculture: The Brazilian Cerrado. Springer.

Huffman GJ, Bolvin DT, Braithwaite D, Hsu K, Joyce R, Kidd C, Nelkin EJ, Sorooshian S, Tan J, and Xie P. (2019a). Integrated Multi-satellitE Retrievals for GPM (IMERG). Algorithm Theoretical Basis Document, National Aeronautics and Space Administration, 38.

Huffman GJ, Stocker EF, Bolvin DT, Nelkin EJ, and Tan J. (2019b). GPM IMERG Final Precipitation L3 1 day 0.1 degree x 0.1 degree V06. Goddard Earth Sciences Data and Information Services Center (GES DISC), Greenbelt, MD.

IBGE. (2017). Censo Agropecuário 2017 [In English: Brazilian Agricultural Census 2017]. Instituto Brasileiro de Geografia e Estatística.

IBGE. (2019). Biomas e Sistema Costeiro-Marinho do Brasil - 1:250 000. Instituto Brasileiro de Geografia e Estatística.

Iglesias A, Garrote L (2015) Adaptation strategies for agricultural water management under climate change in Europe. Agric Water Manag 155:113-124

Klink CA (2014) Policy intervention in the Cerrado savannas of Brazil: Changes in the land use and effects on conservation. A. Consorte-McCrea, \& E. Ferraz Santos, Ecology and Conservation of the Maned Wolf: Multidisciplinary Perspectives, 293-308.

Knoben WJM, Woods RA, Freer JE (2018) A Quantitative hydrological climate classification evaluated with independent streamflow data. Water Resour Res 54(7):5088-5109

Krause P, Boyle DP, Bäse F (2005) Comparison of different efficiency criteria for hydrological model assessment. Adv Geosci 5:89-97

Kueppers LM, Snyder MA, Sloan LC (2007) Irrigation cooling effect: regional climate forcing by land-use change. Geophys Res Lett. https://doi.org/10.1029/2006GL028679 
Lambers H, de Britto Costa P, Oliveira RS, Silveira FAO (2020) Towards more sustainable cropping systems: lessons from native Cerrado species. Theor Exp Plant Physiol 32(3):175-194

Lathuillière MJ, Coe MT, Johnson MS (2016) A review of green- and blue-water resources and their trade-offs for future agricultural production in the Amazon Basin: what could irrigated agriculture mean for Amazonia? Hydrol Earth Syst Sci 20(6):2179-2194

Le Moine, N. (2008). "Le bassin versant de surface vu par le souterrain: une voie d'amélioration des performances et du réalisme des modèles pluie-débit.” Ph.D. thesis, Université Pierre et Marie Curie, Paris.

Lemes L, de Andrade AFA, Loyola R (2020) Spatial priorities for agricultural development in the Brazilian Cerrado: may economy and conservation coexist? Biodivers Conserv 29(5):1683-1700

Lima JEFW (2011) Situação e perspectivas sobre as águas do cerrado. Ciência e Cultura 63(3):27-29

Lima MGB, and Persson UM (2020) "Commodity-Centric Landscape Governance as a Double-Edged Sword: The Case of Soy and the Cerrado Working Group in Brazil." Frontiers in Forests and Global Change, Frontiers, 3.

Malveira VTC, de Araújo JC, Güntner A (2012) Hydrological impact of a high-density reservoir network in semiarid northeastern Brazil. J Hydrol Eng 17(1):109-117

Marques EAG, Silva Junior GC, Eger GZS, Ilambwetsi AM, Raphael P, Generoso TN, Oliveira J, Júnior JN (2020) Analysis of groundwater and river stage fluctuations and their relationship with water use and climate variation effects on Alto Grande watershed, Northeastern Brazil. J South Am Earth Sci 103:102723

McMillan HK (2020) Linking hydrologic signatures to hydrologic processes: A review. Hydrol Process 34(6):1393-1409

Mueller ND, Butler EE, McKinnon KA, Rhines A, Tingley M, Holbrook NM, Huybers P (2016) Cooling of US Midwest summer temperature extremes from cropland intensification. Nat Clim Chang 6(3):317-322

Nash JE, Sutcliffe JV (1970) River flow forecasting through conceptual models part I - A discussion of principles. J Hydrol 10(3):282-290

Pereira SB, Pruski FF, Silva DD, Ramos MM (2009) Evaporação líquida no lago de Sobradinho e impactos no escoamento devido à construção do reservatório. Revista Brasileira De Engenharia Agrícola e Ambiental 13(3):346-352

Pinhati FSC, Rodrigues LN, Aires de Souza S (2020) Modelling the impact of on-farm reservoirs on dry season water availability in an agricultural catchment area of the Brazilian savannah. Agric Water Manag 241:106296

Pires GF, Abrahão GM, Brumatti LM, Oliveira LJ, Costa MH, Liddicoat $\mathrm{S}$, Kato E, Ladle RJ (2016) Increased climate risk in Brazilian double cropping agriculture systems: Implications for land use in Northern Brazil. Agric for Meteorol 228:286-298

Pousa R, Costa MH, Pimenta FM, Fontes VC, de Brito VFA, Castro M (2019) Climate change and intense irrigation growth in western Bahia, Brazil: The urgent need for hydroclimatic monitoring. Water 11(5):933
Pushpalatha R, Perrin C, Le Moine N, Mathevet T, Andréassian V (2011) A downward structural sensitivity analysis of hydrological models to improve low-flow simulation. J Hydrol 411(1-2):66-76

Rada N (2013) Assessing Brazil's Cerrado agricultural miracle. Food Policy. https://doi.org/10.1016/j.foodpol.2012.11.002

Rodrigues LN (2018). Plataforma tecnológica para o gerenciamento compartilhado de água. Empresa Brasileira de Pesquisa Agropecuária.

Rodrigues LN, Sano EE, Steenhuis TS, Passo DP (2012) Estimation of small reservoir storage capacities with remote sensing in the brazilian savannah region. Water Resour Manage 26(4):873-882

Rodrigues JAM, Viola MR, Alvarenga LA, de Mello CR, Chou SC, de Oliveira VA, Uddameri V, Morais MAV (2020) Climate change impacts under representative concentration pathway scenarios on streamflow and droughts of basins in the Brazilian Cerrado biome. Int J Climatol 40(5):2511-2526

Rosa L, Chiarelli DD, Rulli MC, Dell'Angelo J, D'Odorico P (2020) Global agricultural economic water scarcity. Sci Adv Am Ass Adv Sci 6(18):eaaz6031

Souza CM, Shimbo ZJ, Rosa MR, Parente LL, Alencar AA, Rudorff BFT, Hasenack H, Matsumoto M, Ferreira LG, Souza-Filho PWM, de Oliveira SW, Rocha WF, Fonseca AV, Marques CB, Diniz CG, Costa D, Monteiro D, Rosa ER, Vélez-Martin E, Weber EJ, Lenti FEB, Paternost FF, Pareyn FGC, Siqueira JV, Viera JL, Neto LCF, Saraiva MM, Sales MH, Salgado MPG, Vasconcelos R, Galano S, Mesquita VV, Azevedo T (2020) Reconstructing three decades of land use and land cover changes in brazilian biomes with landsat archive and earth engine. Remote Sensing, Multidisciplinary Digital Publishing Institute 12(17): 2735

Spangler KR, Lynch AH, Spera SA (2017) Precipitation drivers of cropping frequency in the Brazilian Cerrado: Evidence and implications for decision-making. Weather, Climate, and Society 9(2):201-213

Spera S (2017) Agricultural intensification can preserve the brazilian cerrado: applying lessons from mato grosso and goiás to brazil's last agricultural frontier. Tropical Conservation Science, SAGE Publications Inc 10:1940082917720662

Westerberg IK, McMillan HK (2015) Uncertainty in hydrological signatures. Hydrol Earth Syst Sci Copernicus GmbH 19(9):3951-3968

Woods RA (2009) Analytical model of seasonal climate impacts on snow hydrology: continuous snowpacks. Adv Water Resour 32(10):1465-1481

Youssef YW, and Khodzinskaya A (2019) A Review of Evaporation Reduction Methods from Water Surfaces. E3S Web of Conferences, 97, 05044.

Publisher's Note Springer Nature remains neutral with regard to jurisdictional claims in published maps and institutional affiliations. 